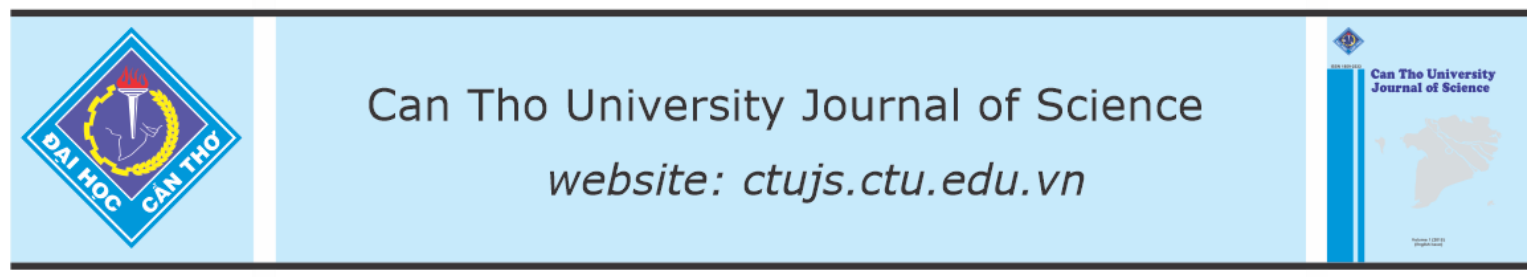

DOI: 10.22144/ctu.jen.2021.039

\title{
Effects of Voki-supported self-practice on high school students' English speaking performance
}

\author{
Nguyen Thi Kieu Diem ${ }^{1 *}$ and Nguyen Van Loi ${ }^{2}$ \\ ${ }^{I}$ Nguyen Thi Minh Khai High School, Soc Trang, Viet Nam \\ ${ }^{2}$ School of Foreign Languages, Can Tho University, Viet Nam \\ *Correspondence: Nguyen Thi Kieu Diem (email: diemM1619007@gstudent.ctu.edu.vn)
}

\section{Article info.}

Received 21 Jun 2021

Revised 28 Jul 2021

Accepted 05 Aug 2021

\section{Keywords}

Satisfaction, speaking performance, Voki, Web 2.0

\begin{abstract}
Web 2.0 applications with multimedia affordances provide a creative way to expose students to a non-threatening environment for practising English. Motivated by the potentials of this type of application for English speaking instruction, this study aimed to examine the effects of high school learners' self-practice using an app called Voki on their speaking performance. A quasi-experimental control group design was employed, in which the effect was measured by means of two speaking tests before and after the treatment, and further explored with a semi-structured interview. The results showed the increase in the students'speaking skills and the satisfaction with this Web 2.0 tool for its effectiveness and engagement. Their shyness and nervousness about uttering the target language diminished as their confidence increased. Accordingly, more evidence of the efficacy of Voki on EFL learners' speaking performance was offered in the study. Future research can investigate learners' improvement in language proficiency in different skills and contexts and involve larger sample sizes.
\end{abstract}

\section{INTRODUCTION}

There has been a growing demand for acquiring English proficiency owing to its increasing role as an international language in the era of globalization. In line with the social nature of language, speaking competence is supposed to be the most critical part of foreign language learning since much of the information is shared through verbal communication (Abugohar et al., 2019). The speaking proficiency, accordingly, has become crucial in the learning process (Nazara, 2011). The term "speaking" has been defined as the ability to produce verbal utterances to express meaning, feelings, and needs (Fulcher, 2003; Nunan, 2003). According to Brown (2007), speaking is a process of constructing meaning, producing, receiving, and processing sounds. In the view of Brown (2004), speaking is a productive skill which can be observed both directly and empirically.

According to several researchers (Harmer, 2001; Mazouzi, 2013; Richards, 2008; Syakur, 1987; Thornbury, 2005), speaking performance involves abilities to manipulate pronunciation, grammar, vocabulary, and fluency. Syakur (1987) refers pronunciation to how a person articulates the target language sounds and sound patterns, while grammar indicates the arrangement of sentences and manipulation of grammatical structures. Knowledge of proper vocabulary use and a range of words applies to lexical resources. Besides, fluency is characterized as the ability to express ideas adequately and maintain a reasonable rate of speech with minimal hesitations. Harmer (2001) and Mazouzi (2013) classify proper use of vocabulary, 
grammar, pronunciation into accuracy. Pronunication ability refers to how precisely one produces target language sounds and phonological features. Lexical accuracy implies the suitable choice of words and word forms. Grammatical accuracy should be performed for a range of structures from basic to complex ones. In the view of Thornbury (2005), accuracy involves making no or few errors in these aspects. In contrast, fluency entails linking ideas by using certain discourse devices such as connective markers, proper stress and intonation (Mazouzi, 2013; Richards, 2008).

Developing the "speaking" ability requires a great deal of effort to practise, especially in a nonauthentic communication environment like the EFL classroom. Research has revealed that EFL students encounter problems in speaking performance. First, anxiety can make them highly susceptible to mistakes in their speech (Woodrow, 2006). Inhibition or unwillingness to communicate can also influence their motivation to engage in speaking English (Abugohar et al., 2019; Nguyen \& Tran, 2015). Zaremba (2006) states that EFL learners typically have few opportunities to speak English outside the classroom, as well as limited exposure to members of the international community. Thus, they should be provided with more speaking opportunities in language classrooms. Another challenge for EFL learners is the English especially stress, intonation, and rhythm pronunciation (Ahmed, 2017). Ahmed (2017) emphasizes that a good pronunciation may enhance EFL learners' confidence in speaking English. To sum up, affective factors, limited opporunties, and the English sound system are unavoidable challenges that the teacher may confront in getting students to speak in the EFL classroom. Thus, they should be exposed to a non-threathening environment that facilitates their speaking practice.

To provide a psychologically safe environment facilitating EFL students' practice, innovative technologies can be used to blend course activities and motivate further practice (Bahadorfar \& Omidvar, 2014; Sharma \& Barret, 2007). In this respect, Web 2.0 applications with multimedia affordances like Voki offer a good option. Web 2.0 was introduced in the work of O'Reilly (2005) to indicate a new generation of web-based technology. In second language education, Web 2.0 tools refer to user-friendly applications that offer a creative, collaborative, communicative and fun learning environment (Dogoriti, 2010). Considering the linguistic and psychological barriers of English learners, they offer an educational solution to promote communication in a stress-free environment (Gray et al., 2012). Voki is a representative example that can offers such affordances for speaking improvement (Schrock, 2012). The tool has three options including Free Voki, Voki Classroom, and Voki Presenter. 'Free Voki' offers individuals affordances for speaking practice whereas 'Voki Classroom' and 'Voki Presenter' help the teacher to run a classroom online. This paper only focuses on Free Voki (Voki) because it can generate students' activities.

In this option, learners can create their own avatars in a fun and imaginative way and record their voices to with peers and teachers. Since there is a limit of 60 seconds in Voki, students need to organize their thoughts carefully so that they can complete their voice recordings within the allotted time several times before uploading. It means that learners can make more utterances, which increases their confidence and fluency in speaking. A small number of recent studies have investigated the contribution of Voki to language education. Picardo (2009) found that the more EFL learners in his study practiced their speaking skills via Voki, the more fluent they became. Eggleton (2012) discovered that when students had a chance to create presentations using Voki, their motivation, confidence and speaking performance improved. Likewise, BellésFortuño and Bellés-Calvera (2018) reported Spanish students' improved pronunciation after an eightweek experiment. In a different context, İstifanoğlu (2020) conducted a case study on primary school students in Turkey, employing Voki for one semester, and concluded that it enhanced the students' confidence in English speaking. Yeşilbağ and Korkmaz (2021) further proved that Voki improved the $5^{\text {th }}$ grade Turkish students' English achievement scores after a six-week treatment.

The review above suggests that the effects of web tools can be justified, but few studies have yet to explore their effect on EFL high school learners' speaking in Viet Nam. Therefore, this study aimed to fill this gap to enrich the literature on the use of educational technology in the $21^{\text {st }}$-century classrooms to promote students' learning. With a view to investigating the effect of using Voki to support learners' speaking self-practice in a highschool context, the study addresses the following research questions: 
(1) What effects does the use of Voki for speaking self-practice have on high school EFL students' speaking performance?

(2) What is the students' feedback on the use of Voki to support their speaking practice?

\section{MATERIALS AND METHODS}

\subsection{Design}

This research was conducted as a quasiexperimental design in which an explanatory mixed methods model was employed to collect data (Gay et al., 2012). The use of Voki in speaking lessons served as the independent variable while students' speaking performance was the dependent variable measured in terms of fluency and coherence, pronunciation, vocabulary, and grammar. The data of the study were collected from pre-and postspeaking tests, and a semi-structured interview.

\subsection{Participants}

The subjects of the study were 47 tenth graders who studied English as a core school subject at a gifted high school in the Mekong Delta in the 2020 - 2021 academic year. The samples belonged to two intact classes, and thus were assigned to two groups: one experiemental group (EG) with 25 students and one control group (CG) with 22 students. The participants met the following requirements in order for the research findings to be more valid. Firstly, they both focused on natural sciences, with the CG majoring in Natural Science and the EG specializing in Physics. In addition, they were almost the same age, at 16 years old. The ratio of females to males in both groups was relatively comparable. The CG had 9 girls $(40.9 \%)$ and 13 boys $(59.1 \%)$, whereas the EG included 10 (40\%) girls and 15 boys (60\%).

Furthermore, they all attained a certain level of lexical resources and grammatical range because they had to achieve a grade of at least 5 marks for the subject of English in the written entrance examination to the school. According to the average scores at the end of the first semester, $68.2 \%$ of students in the CG received an English grade of 8.0 or higher while $72 \%$ of students in the EG scored an 8.0 or better. They were taught the same English textbooks at school, namely Grade 10 English and Bridge to IELTS Pre-Intermediate - Intermediate Student's Book.

On the whole, the groups were homogeneous in their specialization, age, the female-to-male ratio and learing materials. Eight of the students at various levels counted from their mean scores in both pretest and posttest were invited to take part in the interview.

\subsection{Instruments}

To collect quantitative data, speaking tests were employed to measure the students' speaking performance before and after the treatment. The pretest and post-tests were adapted from IELTS Cue Cards, in which the candidates were required to perform a monologue on a general topic between one and two minutes. There was a total of eight topics, each of which contained four prompts that the candidate could use to prepare ideas within one minute. The topics surrounded the description of a favorite picture or photograph in their home, a city or town they have visited and want to come back, an interesting conversation they had with someone, an important occasion they attended, a job they do not want to do in the future, a pollution-affected location they visited, a sport they would like to learn, and a leisure activity they did with their family. Accordingly, the candidates were asked to give an individual talk for one or two minutes without the examiner's interference. Both tests were done in the same way as the students used to practice in the speaking lessons, but the tested topics were selected and adapted to ensure that they minimized the students' reliance on rote learning and memorization.

The pre-test and post-test topics were selected from the themes in the English curriculum for Vietnamese General Education designed for high school students, namely our life, society, environment, and future. These testing topics were chosen from the book "Get ready for IELTS PreIntermediate - Intermediate Student's Book" (Aish et al., 2016) which has the same band score of 3.5 to 4.5 as the learning material "Bridge to IELTS PreIntermediate - Intermediate Student's Book" (Harrison \& Susan, 2013) that both groups used during the treatment. The speaking papers were checked by three colleagues working at the same school as the instructor. They were all accustomed to using IELTS materials to teach English to students in grades 10 and 11 . Together with the instructor, one of them also became a rater of the speaking tests. For further equality and clarity of the questions, the teacher also asked for suggestions from an experienced researcher. Based on their feedback on wording and grammar (e.g., Wh-word and tenses), revision was made. The pre-speaking test Cue Cards were reused in the posttest to ensure the same format and equivalence in terms of 
difficulties and familiarities. There was a mix-up of delivering the Cards to make sure that one student did not have the same topic during the two tests. In other words, all candidates had the same random chance. These strategies made the tests to some extent more reliable and valid.

To collect the qualitative data, a semi-structured interview was conducted to gain more insights into the participants' attitudes towards the use of Voki in their speaking practices. Wilson (2013) notes that the semi-structured interview is useful and convenient for eliciting participants' in-depth opinions. In this case, the choice of semi-structured interviews provided the respondents more freedom and opportunities to express their views on their own. Therefore, the qualitative data are much more reliable and comparable. Because of the COVID-19 pandemic, the interviews were conducted online and recorded through Zoom, instead of face-to-face interactions. The recordings were then transcribed and double-checked before data analysis. To facilitate the responses as well as obtain the depth of data, the interview questions were asked in Vietnamese, the participants' mother tongue.

There were five open-ended questions related to three main categories: effectiveness, engagement, and overall satisfaction with the application. These interview questions were adapted from Hsieh et al.'s (2017) to address the students' feedback on the use of Voki to support their speaking performance. Since the researchers wished to explore more about the effects of using technology for outside-theclassroom learning in the context of EFL oral instruction, the focus of the questions centered on three of the four initial constructs. In answering, the participants were required to (1) indicate how their speaking ability has changed after using Voki to support their speaking performance outside the classroom such as anxiety, confidence, pronunciation; (2) express opinions about the features of Voki regarding installation, operation, recorded practices, etc.; (3) state what they like most about Voki and explain the reason; (4) state what they do not like about Voki or problems they have faced; and (5) express whether they are willing to use Voki in the speaking classes and explain their choice.

\subsection{Procedure}

One of the researchers became the instructor who taught both groups in this study. Before the study, the students were informed of their engagement in the experiment, and were explained about the benefits they might get in participating in the study. They were also ensured that the data relating to their participation would be coded and anynomized. The speaking pre-tests were then administered to both groups. A session was subsequently conducted to guide the EG how to use Voki. The treatment that consisted of eight speaking lessons over 10 weeks followed.

Each lesson lasted 90 minutes and focused on one topic delivered on different days for both groups. In each lesson, the students in both groups practiced the topics under the teacher's guidance, and some were invited to present their speech in front of the class and received feedback from the teacher and their peers. To supplement practice, after school, the EG produced avatars of their own voice recorded on the platform of Voki, which was downloaded into their mobile phones and sent back to the teacher via the Voki website for further review in the following lessons. The teacher briefly reviewed, answered students' questions, provided comments, and facilitated students' speaking practices in the following class. In contrast, the CG were asked to review and practice the topics on their own or with a friend and kept a diary on their work, which was checked by the teacher regularly. The teacher examined what students had done based on their diary in the following session, addressed students' questions, provided comments, and guided students' speaking practices if necessary.

After 10 weeks, the post-test of the same format was administered. During both speaking test sessions, all the participants were mixed up. The total set of eight topic cards was used in circulation. One card was used for two consecutive testees, one after another. As the cards were used up, they were randomly picked and recycled for the rest of testees. All the responses were audio recorded, and then two independent examiners rated the students' performance with 0 being the lowest and 9 for the highest according to the assessment criteria adopted from Assessing Speaking Performance IELTS. Before rating, they discussed the assessment criteria. The pre-test speaking exam took place on the same day in a classroom. Due to the unexpected spread of the coronavirus pandemic in early May, the post-test exam was administered via Zoom, with only one examiner and was recorded. The students' performance recordings were then rated by the other examiner who had taken part in the pretest assessment.

Following the analysis of the data from the speaking tests, a semi-structured interview was undertaken to 
acquire further insight into the participants' perspectives on the use of Voki in their speaking practices. Due to the COVID-19 outbreak, the interviews were conducted online through Zoom, and recorded. Vietnamese was used to avoid miscommunciation.

\subsection{Data analysis}

SPSS was employed to analyze the test data. Pearson Correlations was first run to measure the inter-rater reliability. The coefficients $(r=0.99, p=$ 0.000 ) displayed a strength of agreement between two raters for categorical scales. Accordingly, the mean scores of both raters were the final test scores used for data analysis. Then, the normality of the sample data in the second step was checked by running the Frequencies and the Shapiro-Wilk. The Skewness value obtained was far from the value of zero, indicating that the data displayed asymmetry. In addition, the Shapiro-Wilk results showed that the $p$ value of pretest $(\mathrm{p}=0.008)$ was less than 0.05 , meaning that the data distribution was not normal. In this case, the non-parametric tests: A MannWhitney Test and Wilcoxon Signed-Rank Test were opted in the study.

The pre-test and post-test medians were compared to determine the effectiveness of the application.
Following the analysis of the data from the speaking tests, the researcher interviewed eight students at various levels, namely very good, good, fair, and low, depending on the difference between the EG's two mean values (pretest and posttest). The interview comments were analyzed for three categories, including effectiveness, engagement, and overall satisfaction with the app.

\section{RESULTS}

\subsection{Students' speaking performance before the treatment}

The test results showed that the scale reliability coefficients of both tests were at the same high level $(\alpha=0.986)$, indicating that the tests and the data gathered from them were sufficiently reliable. A Mann-Whitney test was run to check whether there was a difference in speaking performance before the treatment between the CG and the EG. The pre-test mean ranks of the two groups were presented in Table 1. The results indicated that the difference in speaking performance between the two groups was not statistically significant before the treatment $(\mathrm{p}=$ 0.806). It means that the students' speaking performance was the same before the treatment of using Voki to support speaking self-practice outside the classroom.

Table 1. Mean ranks of participants' speaking performance before the treatment

\begin{tabular}{llrrrrr}
\hline & Group & NMean Rank & Sum of Ranks & Mann-Whitney U & $\begin{array}{r}\text { Z } \\
\text { Asymp. Sig. (2-tailed) }\end{array}$ \\
\hline \multirow{2}{*}{ Mpretest } & CG & 22 & 23.48 & 516.50 & 263.5 & -.246 \\
& EG & 25 & 24.46 & 611.50 & .806 \\
\hline
\end{tabular}

3.2. Participants' overall speaking performance after the treatment

The Wilcoxon Signed-Ranks Test, as shown in Table 2, was calculated to determine whether there was a positive change in the CG and the EG's speaking performance. The results indicated that both groups had statistically significant improvement in speaking performance. The mean scores of the post-test were statistically higher than those of the pre-test $(M=3.57 ; Z=-2.541, p=0.011$ for $C G$; and $M=4.44 ; Z=-4.294, p=0.000$ for $E G$, respectively).

Table 2. Within-group differences in mean ranks of speaking performance

\begin{tabular}{lllrrr}
\hline Groups & & N & Mean & Std. Deviation & $\begin{array}{r}\text { Z } \\
\text { Asymp. Sig. (2-tailed) }\end{array}$ \\
\hline \multirow{2}{*}{ CG } & Mpretest & 22 & 3.0625 & 1.33770 & -2.541 \\
& Mposttest & 22 & 3.5739 & 1.38868 & .011 \\
\hline \multirow{2}{*}{ EG } & Mpretest & 25 & 3.2150 & .96910 & -4.294 \\
& Mposttest & 25 & 4.4475 & 1.06015 & .000 \\
\hline
\end{tabular}

Moreover, to determine which group made more progress, the Mann-Whitney Test was run. The results (Table 3) showed that the mean rank for speaking performance of the $\mathrm{EG}(\mathrm{MR}=27.88)$ were statistically different from and that of the CG (MR= 19.59) $(Z=-2.071, p=0.038)$. This means that the EG made far more improvement than the CG. 
Table 3. Difference in mean ranks of participants' speaking performance after the treatment

\begin{tabular}{rccccrr}
\hline & Group & \multicolumn{2}{c}{ N Mean Rank } & \multicolumn{2}{c}{ Sum ofMann-Whitney } \\
Ranks & UAsymp. Sig. (2-tailed) \\
\hline Mposttest & CG & 22 & 19.59 & 431.00 & 178.0 & -2.071 \\
& EG & 25 & 27.88 & 697.00 & & .038 \\
\hline
\end{tabular}

In particular, from Table 4, the EG shifted better than the CG in all aspects including fluency and coherence $(\mathrm{MR}=27.90$ compared to $\mathrm{MR}=19.57)$, lexical resources $(\mathrm{MR}=27.90$ versus $\mathrm{MR}=19.57)$, grammatical range and accuracy $(\mathrm{MR}=28.00$ versus $\mathrm{MR}=19.45)$, and pronunciation $(\mathrm{MR}=27.76$ versus $\mathrm{MR}=19.73)$ with $\mathrm{p}$ values $<0.05$. In other words, the enhancement in speaking skills was statistically significant, but it varied by components. Accordingly, grammatical range and accuracy were boosted the most, followed by fluency and coherence, and lexical resources. The pronunciation abilities increased slightly, not as much as the other components.

Table 4. Differences in mean ranks of four components of speaking performance after the treatment

\begin{tabular}{|c|c|c|c|c|c|c|c|c|c|}
\hline & Group & $\mathbf{N}$ & $\begin{array}{l}\text { Mean } \\
\text { Rank }\end{array}$ & $\begin{array}{r}\text { Sum of } \\
\text { Ranks }\end{array}$ & Mean & $\begin{array}{r}\text { Std. } \\
\text { Deviation }\end{array}$ & $\begin{array}{r}\text { Mann- } \\
\text { Whitney } \\
\mathbf{U}\end{array}$ & $\begin{array}{r}\text { Wilcoxon } \\
\text { W }\end{array}$ & $\begin{array}{r}\mathrm{Z} \\
\text { Asymp. } \\
\text { Sig. (2- } \\
\text { tailed) }\end{array}$ \\
\hline \multirow{2}{*}{$\begin{array}{l}\text { Mpost-fluency } \\
\& \text { coherence }\end{array}$} & CG & 22 & 19.57 & 430.50 & 3.6136 & 1.41574 & \multirow{2}{*}{177.5} & \multirow{2}{*}{430.5} & \multirow{2}{*}{$\begin{array}{r}-2.100 \\
.036 \\
\end{array}$} \\
\hline & EG & 25 & 27.90 & 697.50 & 4.5000 & 1.11337 & & & \\
\hline \multirow{2}{*}{$\begin{array}{l}\text { Mpost - } \\
\text { lexical } \\
\text { resource }\end{array}$} & CG & 22 & 19.57 & 430.50 & 3.6136 & 1.41574 & \multirow[b]{2}{*}{177.5} & \multirow[b]{2}{*}{430.5} & \multirow{2}{*}{$\begin{array}{r}-2.100 \\
.036\end{array}$} \\
\hline & EG & 25 & 27.90 & 697.50 & 4.5000 & 1.11337 & & & \\
\hline \multirow{2}{*}{$\begin{array}{l}\text { Mpost- } \\
\text { grammatical } \\
\text { range \& } \\
\text { accuracy }\end{array}$} & CG & 22 & 19.45 & 428.00 & 3.4432 & 1.30915 & \multirow[b]{2}{*}{175.0} & \multirow[b]{2}{*}{428.0} & \multirow{2}{*}{$\begin{array}{r}-2.199 \\
.028\end{array}$} \\
\hline & EG & 25 & 28.00 & 700.00 & 4.2900 & 1.00177 & & & \\
\hline \multirow{2}{*}{$\begin{array}{l}\text { Mpost- } \\
\text { pronunciation }\end{array}$} & CG & 22 & 19.73 & 434.00 & 3.6250 & 1.52118 & \multirow{2}{*}{181.0} & \multirow{2}{*}{434.0} & \multirow{2}{*}{$\begin{array}{r}-2.041 \\
.041\end{array}$} \\
\hline & EG & 25 & 27.76 & 694.00 & 4.5000 & 1.11803 & & & \\
\hline
\end{tabular}

Generally, the results above indicate that the effect of the Voki group outweighed that of the control group in all aspects of speaking performance.

\subsection{Students' feedback on the use of Voki to support their speaking practice}

Regarding the effectiveness of the application on linguistic features, the interview data showed that all the interviewees agreed that Voki was an effective tool for improving their speaking skills because it enhanced their pronunciation. The belief may slightly differ from the finding above since pronunciation is the least improved among the components. This can be attributed to students being more concerned about Voki's educational affordances in their pronunciation, which was one of the major issues they commonly experienced during speaking lessons. When asked how her speaking ability had changed after using Voki to support her speaking performance outside of the classroom, student A replied, "I can correct my pronunciation immediately after listening to the recording." Sharing this view, student B said, "It also helps me to improve my pronunciation, so that I can do the speaking activities more easily." or as student E, " After using Voki, I find that my pronunciation is much better."

In terms of psychological effects, they all asserted that Voki could help to minimize their fear of speaking English and so increased their confidence, accordingly. They typed their speech, then listened to what Voki said before rehearsing and selfcorrecting their own pronunciation. The more confident they felt in their voice, the less afraid they were to express themselves in English. Student A explained, "Because when I use Voki, I can create a character who will speak English in my place. It will be more interesting than other types of recordings. 
Voki says first, and I can listen and correct my own pronunciation. This makes me feel more comfortable, allowing me to offer my topic with ease. I am also more confident when speaking English in front of a crowd." It was possible that listening and revising their speech many times could make them less worried about their mistakes. Voki read first so that they listened and corrected their pronunciation on their own. They felt as though they had gained more knowledge, and their speaking anxiety gradually decreased when standing in front of a crowd.

Concerning the application engagement, some of them admitted that they had more practice chances. The majority of respondents were interested in a diverse range of speaking characters, which boosted their participation in speaking activities. Student B confirmed, "Well, I used to have few opportunities to speak English", while student A, who achieved the highest difference in the EG, said that she had more chances to self-practice with many exercises assigned in class. The other students believed that they were involved in character selection with diverse backgrounds and voice changers to represent their personalities, making the speech more fascinating. In addition, the majority of respondents consider Voki to be a user-friendly app. They seldom experienced any problems while operating this educational app. Besides, it provided the users a simple layout that made it easier to locate function buttons on Voki such as setting up or recording.

Although the respondents agreed on some of the benefits of Voki to support their speaking skills, many of them complained about the limitations related to the recording time and application speed. Their criticism centered on how time-consuming it is to generate an avatar for each recording and tackle the lag problem. They all felt that the recording time on Voki was relatively brief, making it impossible for students B and $\mathrm{G}$ to cover all of the issues in the speech. Students C, D, E, and $\mathrm{H}$ were afraid that they would have to rebuild the speaking characters every time they left and returned to Voki. What they disliked the most about Voki was that they had to choose their avatar every time they visited the app, which was time-consuming. Student $F$ added to this case that he had to wait a long time because there was occasionally latency. Students at advanced levels who desired to augment their self-study time paid more attention to strengthening functions that might improve linguistic characteristics such as final sounds and grammar. Student A honestly stated, "I hope Voki will allow a little longer recording because people usually speak for 1 to 2 minutes on average in Part 2 of IELTS speaking. And there are some still unclear endings with the recording." or, in the words of student $\mathrm{E}$, "I hope the app can add a grammar correcting section because I'm not very good at that part."

Overall, the participants acknowledged pleasure with the app use to support their at-home speaking practice despite having a range of positive and negative opinions. They all agreed that they were willing to use it again if given a chance.

\section{DISCUSSION}

The most remarkable finding of the study was that the students supported by Voki in their at-home speaking practice performed significantly better on the post-test in terms of fluency and coherence, lexical resources, grammatical range and accuracy, and pronunciation than those taught without the support of Voki. The students also highly appreciated the use of Voki since their confidence, along with certain linguistic features in second language acquisition, improved. In addition, their shyness began to lessen as they became more engaged in speaking practices. Such findings were consistent with previous research (Bellés Calvera \& Bellés Fortuño, 2018; Eggleton, 2012; İstifanoğlu, 2020; Picardo, 2003; Yeşilbağ \& Korkmaz, 2021). For example, in line with Picardo (2003), the study confirmed the increase in fluency and confidence in speaking.

The study also found that the creativity of the speech inspired the participants, resulting in a considerable shift in attitudes from shyness towards confidence in speaking skills, as illustrated by the findings in Eggleton (2012) and İstifanoğlu (2020). In line with the findings of Bellés Calvera and Bellés Fortuo (2018), this study confirmed the potential of learners' increased pronunciation performance through the use of Voki. The results in Yeșilbağ and Korkmaz (2021) indicated that the Voki application had no considerable impact on students' level of listening, reading, and writing, but speaking. This study reconfirmed that the Voki application had a significant effect on learners' academic achievement in terms of speaking performance.

Surprisingly, the growth in the linguistic aspect "grammatical range and accuracy" and "lexical resources" was added to the effect of using multimedia web tools to support learners' speaking self-practice in a high-school context. Some 
students commented that their grammar accuracy improved as the more they practised with Voki, the more familiar they became with particular structures and the usage of tenses. This could explain why the participants' speech was more grammatically correct, and they could employ more certain simple patterns.

In terms of the impact on vocabulary range and accuracy, several respondents stated that because they used Voki so frequently to work with topic-bytopic cue cards, they could remember more phrases. They had an opportunity to revise words from the textbook or those they had learned when they performed their speech on Voki. Because the recording time afforded by the tool was limited, they had to limit the quantity of topic-related words they used. Accordingly, the more time they spent preparing and subsequently participating in a Voki speech, the more vocabulary they learnt, ranging from simple words to topic-related academic terms. In general, despite the lack of grammar correction or word choice functions in Voki, students' vocabulary and grammatical structures were expanded. It could be concluded that the number of words and patterns students could recall was directly proportional to the number of times they engaged.

Although the participants acknowledged satisfaction with the use of Voki to enhance their academic achievement, as in previous studies (Bellés Calvera \& Bellés Fortuño, 2018; Eggleton, 2012; İstifanoğlu, 2020; Picardo, 2003; Yeşilbağ \& Korkmaz, 2021), they also made recommendations to make the app more perfect. To be more specific, they mentioned several drawbacks they encountered, such as the limits of recording time and application speed issues. The length of time required to create an avatar for each recording was also listed.

To sum up, Web 2.0 tools have paved the way for second language instruction in the digital age. Voki, in particular, has the potential to improve language learning outcomes, notably speaking performance, via the educational technology tool. The study adds to the previous relevant literature on the use of Web 2.0 tools in the EFL context, which may highlight

\section{REFERENCES}

Abugohar, M. A., Al-Hnifat, M. A., Al-Smadi, O. A., Rashid, R. A., \& Yunus, K. (2019). English language speaking skill issues in an EMP context: Causes and solutions. International Journal of English Linguistics, 9(3), 211-225. the need for new Education Technology tools to be used in 21st-century classrooms to promote students' language proficiency.

\section{CONCLUSIONS}

Technology is part of almost every aspect of daily life in the $21^{\text {st }}$ century since it has profoundly affected the method of second language learning and teaching. There has been a great deal of research on the feasibility of language education using technology. In terms of developing learning outcomes through the educational technology tool in a fun and creative way, particularly speaking performance, the current study is likely to make a valuable contributions to the relevant literature about using Web 2.0 in the EFL context. The findings of the current study suggest that the Web 2.0 tools in general, and Voki in particular, potentially improve students' language proficiency. This application engages and motivates the participants in self-practice speaking activities. Accordingly, their shyness and nervousness about uttering the target language can diminish and their confidence increases.

In paricular, the study offers more evidence of the efficacy of Voki to support learners' speaking selfpractice in a high-school context where students have been allowed to use smartphones for academic purposes. In addition, the internet has enabled the introduction of numerous innovative technological tools into the language classroom. Therefore, students can promote their language learning process with many Web 2.0 tools available on cell phones. Students can use them in any place and as many times as they wish because of its flexibility. Future research could lengthen the experiment time and investigate the improvement in language proficiency in different skills and contexts. Given the limitation in generalizability due to the nonrandom assignment and small sample size, future research that employs larger sample sizes and investigates students' learning of different skills would add further understanding of the effects of Web 2.0 tools.

Ahmed, Z. A. D. A. (2017). Difficulties encountered by EFL students in learning pronunciation: A case study of Sudanese higher secondary schools. International Journal of English Linguistics, 7(4), 75-82.

Aish, F., Short, J., \& Snelling, R. (2016). Get ready for IELTS-student's book: Pre-intermediate to Intermediate IELTS band 3.5-4.5. London: Collins 
Bahadorfar, M., \& Omidvar, R. (2014). Technology in teaching speaking skill. Acme International Journal of Multidisciplinary Research, 2(4), 9-13.

Bellés-Fortuño, B., \& Bellés-Calvera, L. (2018). Teaching English pronunciation with OERs: The case of Voki. Sintagma: Revista de Lingüistica, 30, 57-80.

Brown, H. D. (2004). Language assessment: Principles and classroom practices. Pearson Education.

Brown, H. D. (2007). Principles of language learning \& teaching $\left(5^{\text {th }}\right.$ ed.). Pearson Education.

Dogoriti, E. (2010). Perceptions and attitudes towards web-based ELT among English teachers in Greece. In The 3rd edition of the ICT for language learning conference (pp. 5-7).

Pixel.https://conference.pixelonline.net/conferences/I CT4LL2010/common/download/Proceedings_pdf/S LA24-Dogoriti,Pagge.pdf

Eggleton, B. (2012). Firing the creative juices through voki and prezi-year 7 boys deliver! http://www.theibsc.org/uploaded/IBSC/Action_Rese ach/AR_2012-13/Eggleton_FinalReport.pdf

Fulcher, G., \& Reiter, R. M. (2003). Task difficulty in speaking tests. Language testing, 20(3), 321-344. https://doi.org/10.1191/02655322031t259oa

Gay, L. R., Mills, G. E., \& Airasian, P. W. (2012). Educational research: Competencies for analysis and applications (10th eds). Pearson.

Gray, K., Waycott, J., Clerehan, R., Hamilton, M., Richardson, J., Sheard, J., \& Thompson, C. (2012). Worth it? Findings from a study of how academics assess students' web 2.0 activities. Research in Learning technology, 20. https://doi.org/10.3402/rlt.v20i0.16153

Harrison, L., \& Hutchinson, S. (2013). Bridge to IELTSstudent's book: Pre-intermediate to intermediate IELTS band 3.5-4.5. Andover: National Geographic Learning

Harmer, J. (2001). The practice of English language teaching. Pearson Education Limited.

Hsieh, J.S. C., Wu, W. C. V., \& Marek, M. W. (2017). Using the flipped classroom to enhance EFL learning. Computer Assisted Language Learning, 30(1-2), 1-21. https://doi.org/10.1080/09588221.2015.1111910

İstifanoğlu, E. G. (2020). The influence of voki on learners' speaking skill in the EFL context: A case study with young learners (master's thesis). Çăg Üniversitesi Sosyal Bilimler Enstitüsü.

Mazouzi, S. (2013). Analysis of some factors affecting learners' oral performance. A case study: 3rd year pupils of Menaa's middle schools (master's thesis). University of Biskra Repository.

Nazara, S. (2011). Students' perception on EFL speaking skill development. Journal of English Teaching, 1(1), 28-43. https://doi.org/10.33541/jet.v1i1.50

Nguyen, T. H., \& Tran, M. N. (2015). Factors affecting students' speaking performance at Le Thanh Hien high school. Asian journal of educational research, $3(2), 8-23$.

Nunan, D. (2003). Practical English language teaching. Mc Graw Hill

O'reilly, T. (2005). What is Web 2.0? Design patterns and business models for the next generation of software. In Donelan, H. M., Kear, K. L., \& Ramage, M (Eds.), Online communication and collaboration: $A$ reader (pp. 225-235). Routledge.

Picardo, J. (2009). Using blogs and Voki to increase motivation and oral participation amongst boys in modern foreign languages. https://www.slideshare.net/boxoftricks/using-blogsand-voki-to-increase-motivation-and-oralparticipation-amongst-boys-in-modern-foreignlanguages

Richards, J. C. (2008). Teaching listening and speaking: From theory to practice. Cambridge University Press.

Schrock, B. (2012). Educational technology for $K-12$ teachers. Maryville College.

Sharma, P., \& Barrett, B. (2007). Blended learning: Using technology in and beyond the language classroom. Macmillan Education.

Syakur, S. (1987). The component of speaking skills. Cambridge University Press

Thornbury, S. (2005). How to teach speaking. Pearson Educational Limited.

Woodrow, L. (2006). Anxiety and speaking English as a second language. RELC Journal, 37(3), 308-328. https://doi.org/10.1177/0033688206071315

Yeşilbağ, S., \& Korkmaz, Ö. (2021). The effect of Voki application on students' academic achievements and attitudes towards English course. Education and Information Technology, 26(1), 465-487. https://doi.org/10.1007/s10639-020-10264-7

Zaremba, A. J. (2006). Speaking professionally. Thompson South-Western. 